\title{
FIRST RECORD OF LUTJANUS XANTHOPINNIS (ACTINOPTERYGII: PERCIFORMES: LUTJANIDAE) FROM THE ANDAMAN ISLANDS, INDIA
}

\author{
Jayasimhan PRAVEENRAJ ${ }^{1 *}$, Naganathan DANIEL ${ }^{2}$, Rajendran KIRUBA-SANKAR ${ }^{1}$, \\ and Subhrendu S. MISHRA ${ }^{3}$ \\ ${ }^{1}$ Indian Council of Agricultural Research-Central Island Agricultural Research Institute (ICAR-CIARI), Port Blair, \\ Andaman and Nicobar Islands, India \\ ${ }^{2}$ Indian Council of Agricultural Research-Central Institute of Fisheries Education, Mumbai, India \\ ${ }^{3}$ Zoological Survey of India, Marine Fish Section, Kolkata, India
}

Praveenraj J., Daniel N., Kiruba-Sankar R., Mishra S.S. 2018. First record of Lutjanus xanthopinnis (Actinopterygii: Perciformes: Lutjanidae) from the Andaman Islands, India. Acta Ichthyol. Piscat. 48 (4): 393-397.

Abstract. This study provides the first record of Lutjanus xanthopinnis Iwatsuki, Tanaka et Allen, 2015 from the Andaman Islands. The new record is based on 2 specimens, 123 and $154 \mathrm{~mm} \mathrm{SL}$, captured inshore of Dignabad, Port Blair, Andaman Islands, India. The fish were examined, described, and illustrated. Morphometric and morphological data confirmed that the specimens examined from the Andamans are L. xanthopinnis, which varies distinctly from a closely-related species Lutjanus madras (Valenciennes, 1831).

Keywords: reef fish, Nicobar Islands, Port Blair, marine fish, snapper

\section{INTRODUCTION}

The family Lutjanidae consists of 17 genera and 112 species that are primarily associated with coral reefs in tropical and subtropical regions of the Atlantic and IndoPacific (Fricke et al. 2018). Rajan et al. (2013) reported 44 species from 10 genera from the Andaman and Nicobar Islands of India, including 27 species from the genus Lutjanus. During a recent visit to a fish landing centre in Port Blair in the Andaman Islands, a species of Lutjanus Bloch, 1790 resembling Lutjanus madras (Valenciennes, 1831) was encountered, which on further examination was determined to be Lutjanus xanthopinnis Iwatsuki, Tanaka et Allen, 2015. Lutjanus xanthopinnis is thus herein reported for the first time from the Andamans after detailed comparative morphometric study with L. madras collected from the Andaman Islands and along with data taken from the published description of L. xanthopinnis.

\section{MATERIAL AND METHODS}

Fish specimens were acquired from inshore fishermen selling their catch at the Dignabad fish landing centre, Port Blair, Andaman Island coast. The species was identified following Iwatsuki et al. (2015). The methodology for counts and measurements follows Allen and Talbot (1985) and Iwatsuki et al. (1993). Fish body measurements to the nearest $0.01 \mathrm{~mm}$ were taken using Mitutoyo
CD-6"ASX digital calliper, and results were expressed in $\%$ of standard length (SL). Numbers in parentheses (in the Description) denote the frequency of the count. Scales on the pre-opercular flange and shape of the posterior nostrils were observed in a stereozoom microscope after staining with methylene blue. Specimens used in the study were deposited in the marine fish collection of the Central Island Agricultural Research Institute (CIARI/MF).

\section{RESULTS}

Family LUTJANIDAE

Lutjanus xanthopinnis Iwatsuki, Tanaka et Allen, 2015

Figs. 1, 2, Tables 1, 2

Type locality: Kishira, Kimotsuki, Uchinoura Bay, Kagoshima, Japan, $31^{\circ} 11^{\prime} 26^{\prime \prime} \mathrm{N}, 131^{\circ} 00^{\prime} 3^{\prime \prime} \mathrm{E}$.

Material examined. CIARI/MF-02-03, 2 specimens, 123 and $154 \mathrm{~mm} \mathrm{SL}$, inshore of Dignabad, Port Blair, Andaman Islands, India (11 $\left.40^{\prime} 37.22^{\prime \prime} \mathrm{N}, 92^{\circ} 44^{\prime} 26.48^{\prime \prime} \mathrm{E}\right)$, N. Daniel, 10 May 2017.

Comparative specimen. Lutjanus madras, CIARI/MF-04, 1 specimens, $190 \mathrm{~mm} \mathrm{SL}$, Bathubasti fish market, Port Blair, Andaman Islands, India (11 $\left.37^{\prime} 27.50^{\prime \prime} \mathrm{N}, 92^{\circ} 42^{\prime} 52.95^{\prime \prime} \mathrm{E}\right)$, N. Daniel, 13 May 2017.

Description. Dorsal fin with 10 spines and 13 rays; analfin with 3 spines and 8 branched rays, pectoral-fin rays

* Correspondence: Mr J. Praveenraj, Scientist, Division of Fisheries Science, ICAR-CIARI, Port Blair, Andaman and Nicobar Islands, India 744101, phone: +919679557538, e-mail: (JP)jpr948@gmail.com, (ND) danielfnft@gmail.com, (RKS) rkirubasankar@gmail.com, (SSM) subhrendumishra@gmail.com. 
1 unbranched 14 branched rays; caudal fin emarginated with 2 principle caudal ray at both lobes and 15 branched medial rays; pelvic fin with one spine and 4 branched rays; lateral line scales 49 (1), 50 (1): horizontal scale rows above and below lateral line 6 (2), 13 (2); scale rows on cheek 5 (2); several embedded scales on preopercular flange; pre-dorsal scales extending forward to middle of inter-orbital bisecting the eye perpendicularly. Total gill rakers 22 (2) (including rudiments); Posterior nostrils elliptical and present on each side of snout. A pair of dagger-like canine teeth in the upper jaw followed by a series of small canine-like teeth between it and the lateral part with numerous canine-like teeth. Table 1 provides values of morphometric characters and Fig. $1 \mathrm{~A}$ illustrates the general appearance of the specimen collected.

Coloration of the fresh specimen. Background colour reddish to pinkish to silvery-grey on the dorsum with the whitish abdomen, dark pinkish on the upper head and back;
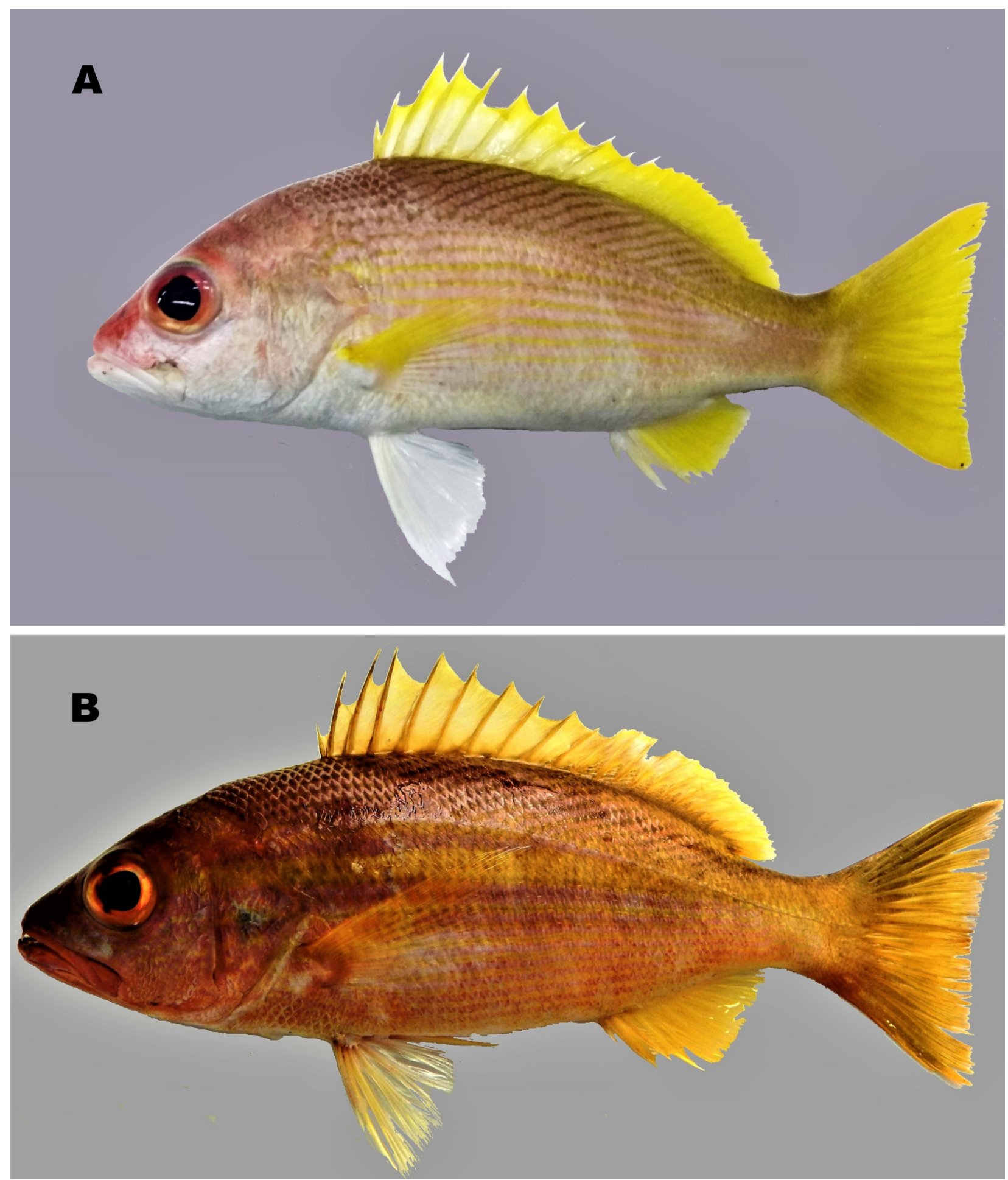

Fig. 1. Lutjanus xanthopinnis, $123 \mathrm{~mm}$ SL; CIARI/MF-02 (A); Lutjanus madras, $190 \mathrm{~mm}$ SL; CIARI/MF-04 (B) (Coloration prior to preservation) 
thin yellow to brownish yellow lines above the lateral line, running obliquely upward and a series of narrow yellow horizontal stripes on lower sides of the body below the lateral line. Dorsal, caudal, anal, and pectoral fins bright yellow; pelvic fins whitish with a yellow tinge.

Distribution. This species is known to occur widely in the western Pacific Ocean from southern Japan to the East Indies, also in the Philippines, Brunei, Malaysia, western Indonesia, northward to China, Taiwan, and extending into the Andaman Sea off the coast of western Thailand (Iwatsuki et al. 2015). It may possible that several records of Lutjanus madras from various localities referable to this species which need to be revisited.

\section{DISCUSSION}

The Andaman and Nicobar Islands are in close proximity to the south-east Asian countries and possess an ichthyofauna assemblage of both Indian and Pacific Ocean
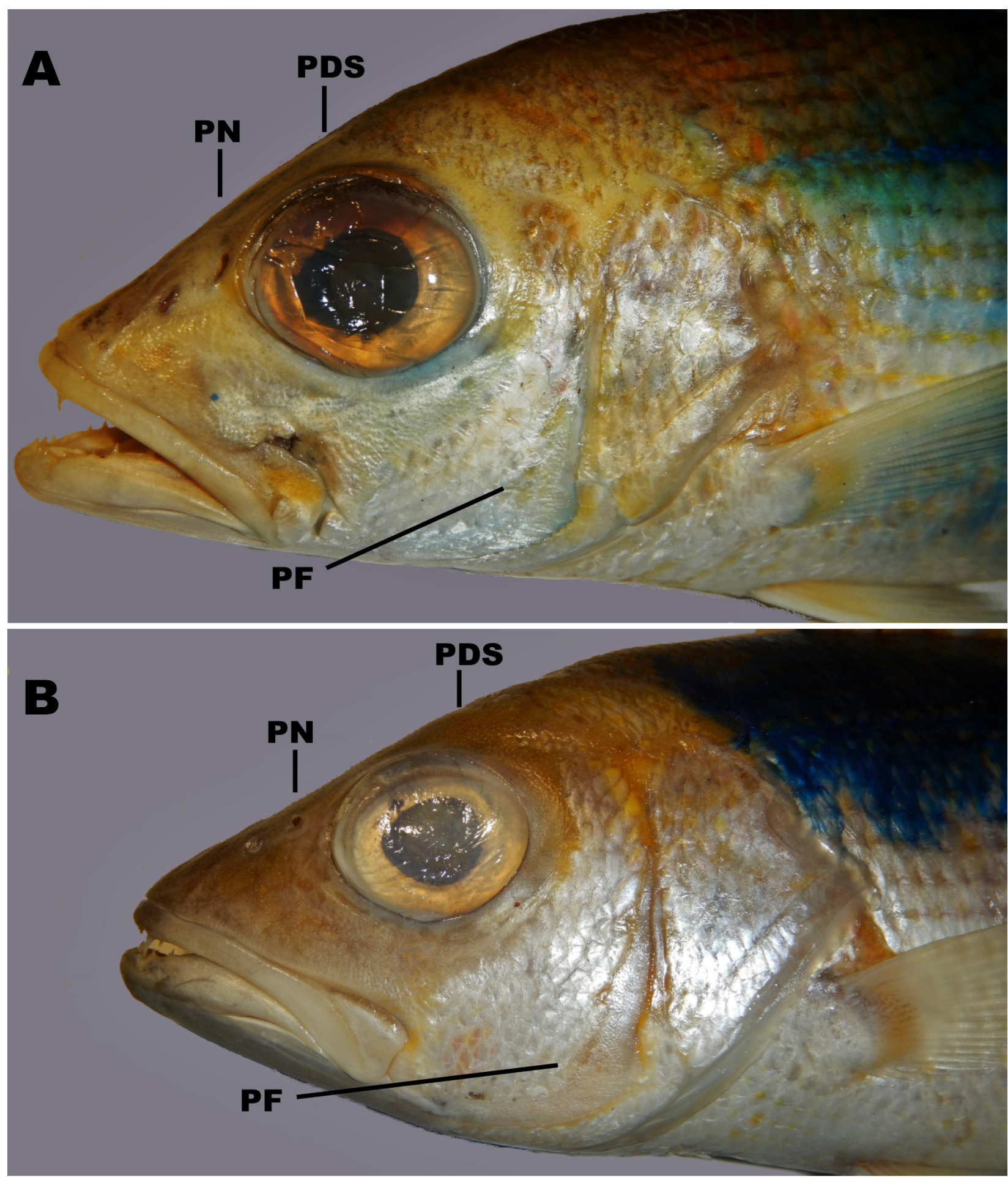

Fig. 2. Lutjanus xanthopinnis; CIARI/MF-02 (A); Lutjanus madras; CIARI/MF-04 (B); PN = posterior nostril, PDS = pre-dorsal scales; $\mathrm{PF}=$ pre-opercular flange 
fishes (Rajan et al. 2013). Previous studies on the reef in L. xanthopinnis. Furthermore, L. xanthopinnis can be fishes of the Andaman Islands have not reported Lutjanus xanthopinnis, presumably because the species was only recognized as being distinct from L. madras in 2015. Indeed, distinguished from L. madras in having an elliptical-shaped posterior nostril (vs. pear shaped); pre-opercular flange with the species was reported as L. madras from the Andaman Sea off the Thailand coast by Iwatsuki and Satapoomin (2009) (see Iwatsuki et al. 2015). Our observations on the inshore fisheries of the Andaman Islands show that L. xanthopinnis occurs sympatrically with $L$. madras and is a common inhabitant of coral reefs and old harbours around Port Blair. It is regularly fished and landed in the markets along with L. madras. Superficially, L. xanthopinnis and L. madras look similar but can be differentiated by the coloration and stripes. Lutjanus madras possesses a bright yellow colour on the caudal flank and in the upper half of scales vs. absence of scales; series of scales above the orbit exactly perpendicular in bisecting the eye diameter into two equal halves vs. bisecting the eye only in the posterior eye margin (Fig. 2A, 2B). The morphometry and meristic data recorded for L. xanthopinnis from the Andamans are within the range published in the original species description by Iwatsuki et al. (2015), except for the pectoral fin ray count, which is 15 in the Andaman specimen vs. 16-17 in the type series. These minor intraspecific variations in the Lutjanidae were also reported in L. madras by Muto et al. (2017). The presently reported study constitutes the first record of L. xanthopinnis from Indian waters (an the posterior dorsal vs. dull yellow over the caudal flanks important extension of its distributional range westward to

Proportional measurements (as percentage of SL) for Lutjanus xanthopinnis (CIARI/MF-02-03)

Table 1 and Lutjanus madras (CIARI.MF-04)

\begin{tabular}{|c|c|c|c|c|c|}
\hline & $\begin{array}{l}\text { L. xanthopinnis } \\
\text { CIARI/MF-02 }\end{array}$ & $\begin{array}{l}\text { L. xanthopinnis } \\
\text { CIARI/MF-03 }\end{array}$ & $\begin{array}{c}\text { L. xanthopinnis } \\
\text { Iwatsuki et al. } 2015\end{array}$ & $\begin{array}{c}\text { L. madras CIARI/ } \\
\text { MF-04 }\end{array}$ & $\begin{array}{c}\text { L. madras } \\
\text { Iwatsuki et al. } 2015\end{array}$ \\
\hline Standard length & $123 \mathrm{~mm}$ & $154 \mathrm{~mm}$ & $56-192 \mathrm{~mm}$ & $190 \mathrm{~mm}$ & $224-254 \mathrm{~mm}$ \\
\hline Body depth & 35.4 & 34.4 & $34-38$ & 33.8 & 34-37 \\
\hline Body depth at 1 st anal spine & 34.4 & 33.7 & $29-34$ & 30.3 & $29-30$ \\
\hline Head length & 39.7 & 38.2 & $37-40$ & 40.2 & $38-40$ \\
\hline Body width & 17.8 & 15.7 & $15-18$ & 14.9 & $13-15$ \\
\hline Snout length & 11.7 & 10.7 & $10-12$ & 13.0 & $11-13$ \\
\hline Orbit diameter & 11.5 & 9.8 & $10-13$ & 10.0 & $10-11$ \\
\hline Dermal eye opening & 9.7 & 9.1 & $9-11$ & 9.3 & 9 \\
\hline Inter-orbital width & 6.1 & 5.9 & $6-7$ & 7.7 & 8 \\
\hline Inter-orbital width + membrane & 8.7 & 7.8 & $8-9$ & 10.3 & 10 \\
\hline Upper jaw length & 15.8 & 15.1 & $11-16$ & 16.6 & $11-16$ \\
\hline Suborbital depth & 6.8 & 5.4 & $5-7$ & 4.8 & $4-5$ \\
\hline Caudal peduncle depth & 12.3 & 11.9 & 12 & 12.3 & 12 \\
\hline Caudal peduncle length & 19.1 & 18.9 & $18-21$ & 19.4 & $18-19$ \\
\hline Pre-dorsal length & 44.8 & 40.3 & $37-44$ & 42.2 & $40-42$ \\
\hline Pre-anal length & 69.3 & 68.4 & $63-68$ & 68.3 & $65-67$ \\
\hline Pre-pelvic length & 40.6 & 38.1 & $36-42$ & 40.3 & $40-41$ \\
\hline Dorsal-fin base & 51.9 & 52.5 & $47-54$ & 51.8 & $49-51$ \\
\hline Anal-fin base & 14.9 & 14.2 & $13-15$ & 15.3 & 15 \\
\hline Caudal-fin length & 27.3 & 26.7 & $23-29$ & 25.7 & $25-29$ \\
\hline Pelvic-fin spine length & 12.3 & 11.9 & $12-21$ & 11.5 & $12-14$ \\
\hline Pelvic-fin length & 20.5 & 18.9 & $19-23$ & 20.3 & $21-22$ \\
\hline Pectoral-fin length & 30.7 & 28.7 & $28-34$ & 29.0 & $27-31$ \\
\hline First dorsal-fin spine & 6.2 & 5.9 & $5-6$ & 4.8 & $5-6$ \\
\hline Second dorsal-fin spine & 12.5 & 11.8 & $11-13$ & 11.3 & $9-11$ \\
\hline Third dorsal-fin spine & 15.2 & 15.9 & $14-16$ & 14.3 & $13-14$ \\
\hline Fourth dorsal-fin spine & 15.1 & 16.1 & $14-17$ & 14.8 & $14-16$ \\
\hline Fifth dorsal-fin spine & 16.3 & 15.4 & $13-16$ & 13.4 & 14 \\
\hline Sixth dorsal fin spine & 13.3 & 14.1 & $11-15$ & 13.2 & $9-14$ \\
\hline First soft dorsal-fin ray & 4.7 & 11.8 & $11-13$ & 11.1 & $10-12$ \\
\hline First anal-fin spine & 4.7 & 5.2 & $3-7$ & 4.0 & $3-4$ \\
\hline Second anal-fin spine & 11.2 & 11.7 & $11-14$ & 9.9 & 10 \\
\hline Third anal-fin spine & 12.3 & 12.3 & $11-14$ & 9.5 & $9-10$ \\
\hline First soft anal-fin ray & 13.9 & 12.8 & $13-16$ & 11.7 & $13-15$ \\
\hline
\end{tabular}


Table 2

Meristic counts for Lutjanus xanthopinnis and Lutjanus madras

\begin{tabular}{|c|c|c|c|c|c|}
\hline & $\begin{array}{l}\text { L. xanthopinnis } \\
\text { CIARI/MF-02 }\end{array}$ & $\begin{array}{l}\text { L. xanthopinnis } \\
\text { CIARI/MF-03 }\end{array}$ & $\begin{array}{l}\text { L. xanthopinnis } \\
\text { Iwatsuki et al. } 2015\end{array}$ & $\begin{array}{c}\text { L. madras CIARI/ } \\
\text { MF-04 }\end{array}$ & $\begin{array}{c}\text { L. madras } \\
\text { Iwatsuki et al. } 2015\end{array}$ \\
\hline Dorsal-fin rays & $\mathrm{X}, 13$ & $\mathrm{X}, 13$ & $\mathrm{X}, 13$ & $\mathrm{X}, 13$ & $\mathrm{X}, 13$ \\
\hline Anal-fin rays & III, 8 & III, 8 & III, 8 & III, 8 & III, 9 \\
\hline Pectoral-fin rays $(i+15+i)$ & 15 & 15 & $16-17$ & 17 & 17 \\
\hline \multicolumn{6}{|l|}{ Caudal-fin rays } \\
\hline Lateral-line scales & 49 & 49 & $48-50$ & 51 & $49-51$ \\
\hline Scale rows on cheek & 5 & 5 & $4-5$ & 7 & $7-8$ \\
\hline Scale rows above lateral line & $61 / 2$ & $71 / 2$ & $61 / 2-71 / 2$ & $71 / 2$ & $71 / 2$ \\
\hline Scale rows below lateral line & $13 \frac{1}{2}$ & $13 \frac{1}{2}$ & $11 \frac{1}{2}-14^{1 / 2}$ & $171 / 2$ & $16^{1 / 2}-171 / 2$ \\
\hline Gill rakers, upper and lower & & & $7-8(6-7)+$ & & $8-9(7-8)+$ \\
\hline limb totals (rudiments) & 22 & 22 & $14-15(4-5)$ & 25 & $17-18(7-8)$ \\
\hline$=$ total including rudiments & & & $=22-23$ & & $=25-27$ \\
\hline
\end{tabular}

the Andaman Islands) and also increases to 28 the number of Lutjanus species known to occur in the Andaman and Nicobar Islands.

\section{ACKNOWLEDGEMENTS}

We would like to acknowledge the literature support provided by Dr Ronald Fricke from the State Museum of Natural History Stuttgart, Germany. Thanks are also offered to ICAR-CIARI for providing the Marine Hill research facility for the examination of the specimens and to Deepak Ganguly, Mumbai for preparation of the images.

\section{REFERENCES}

Allen G.R., Talbot J.H. 1985. Review of the snappers of the genus Lutjanus (Pisces: Lutjanidae) from the Indo-Pacific, with the description of a new species. Indo-Pacific Fishes, Vol. 11. Bernice Pauahi Bishop Museum, Honolulu HI, USA.

Fricke R., Eschmeyer W.N., van der Laan R. (eds.) 2018. Catalog of fishes: Genera, species, references. California Academy of Sciences, San Francisco, USA. [Accessed on 15 December 2018.] http://researcharchive.calacademy.org/research/ ichthyology/catalog/fishcatmain.asp
Iwatsuki Y., Akazaki M., Yoshino T. 1993. Validity of a lutjanid fish, Lutjanus ophuysenii (Bleeker) with a related species, L. vitta (Quoy et Gaimard). Japanese Journal of Ichthyology 40 (1): 47-59. DOI: 10.11369/ jji1950.40.47

Iwatsuki Y., Satapoomin U. 2009. Lutjanidae, Snappers. Pp. 135-143. In: Kimura S., Satapoomin U., Matsuura K. (eds.) Fishes of Andaman Sea: West coast of southern Thailand. National Museum of Nature and Science, Tokyo, Japan.

Iwatsuki Y., Tanaka F., Allen G.R. 2015. Lutjanus xanthopinnis, a new species of snapper (Pisces: Lutjanidae) from the Indo-west Pacific, with a redescription of Lutjanus madras (Valenciennes 1831). Journal of the Ocean Science Foundation 17: 22-42.

Muto N., Alama U.B., Kakioka R., Babaran R.P., Motomura H. 2017. First record of Lutjanus madras (Perciformes: Lutjanidae) from the Pacific Ocean, with comments on its intraspecific morphological variation. Cybium 41 (3): 295-298.

Rajan P.T., Sreeraj C.R., Immanuel T. 2013. Fishes of Andaman and Nicobar Islands: A checklist. Journal of the Andaman Science Association 18 (1): 47-87.

Received: 5 January 2018 Accepted: 12 July 2018 Published electronically: 31 December 2018 